\title{
LA MADONA DE MADRID: UNA DONACIÓN DE SANCHO IV AL CONVENTO DE SANTO DOMINGO EL REAL DE MADRID
}

\author{
DiAna LuCÍA GómEZ-CHACÓN ${ }^{1}$ \\ Universidad Politécnica de Madrid
}

\begin{abstract}
La Madona de Madrid, procedente del desaparecido monasterio de Santo Domingo el Real de Madrid, demolido en 1869 , ha sido siempre considerada una donación regia, como consecuencia de los castillos y leones que decoran su peana. Ha sido relacionada con monarcas castellanos como Fernando III, Pedro I y Enrique II, y con personajes próximos a la corona, como sor Constanza de Castilla, atribuyéndole, por lo tanto, una cronología que abarca desde 1219 — año de la fundación del convento - , hasta 1478 — fecha de fallecimiento de la mencionada priora - Sin embargo, tanto la pertenencia de esta imagen al tipo mariano vasco-navarro-riojano, datado en el último tercio del siglo XIII, como el análisis del patronazgo artístico de Sancho IV y su entorno, señalan a este monarca como posible donante de la imagen.
\end{abstract}

Palabras clave: Madona de Madrid; Santo Domingo el Real de Madrid; Sancho IV; Castilla; siglo XIII; patronazgo regio; Orden de Predicadores; dominicas; imaginería mariana.

\section{THE MADONA DE MADRID. A DONATION OF SANCHO IV DE CASTILLA TO THE CONVENT OF SANTO DOMINGO EL REAL}

The Madona de Madrid, from the former convent of Santo Domingo el Real de Madrid, demolished in 1869, has always been considered a royal donation, due to the castles and lions that decorate its base. It has been related to several Castilian monarchs, such as Fernando III, Pedro I and Enrique II, as well as to persons close to the Crown, as, for example, Sister Constanza de Castilla. Therefore, it has been dated between the foundation of the monastery in 1219 and the death of Sister Constanza, in 1478. Nevertheless, the classification of this Marian image as a clear example of the tipo vasco-navarro-riojano, dated to the last third of the $13^{\text {th }}$ century, and along with the analysis of the artistic patronage of Sancho IV and his court, point to this monarch as being the possible donor of the image.

Key words: Madona de Madrid; Santo Domingo el Real de Madrid; Sancho IV; Castile; $13^{\text {th }}$ century; royal patronage; Order of Friars Preachers; Dominican nuns; Marian imagery.

Cómo citar este artículo / Citation: Lucía Gómez-Chacón, Diana (2018): "La Madona de Madrid: una donación de Sancho IV al convento de Santo Domingo El Real de Madrid". En: Archivo Español de Arte, vol. 91, núm. 364, Madrid, pp. 333-348. https://doi.org/10.3989/aearte.2018.20.

"Vueltas las monjas al monasterio después de la terminación de la guerra, acaso se hubiera visto demolido más adelante, á no haberse opuesto á ello el entonces Regente del Reino, Duque de la Victoria; y hoy, vemos con verdadera satisfacción que ha sido exceptuado de las demás iglesias y edificios mandados derribar, y que en verdad bien poco ofrecían de notable.

\footnotetext{
1 diana.lucia@upm.es / ORCID iD: http://orcid.org/0000-0002-0197-7185.
} 


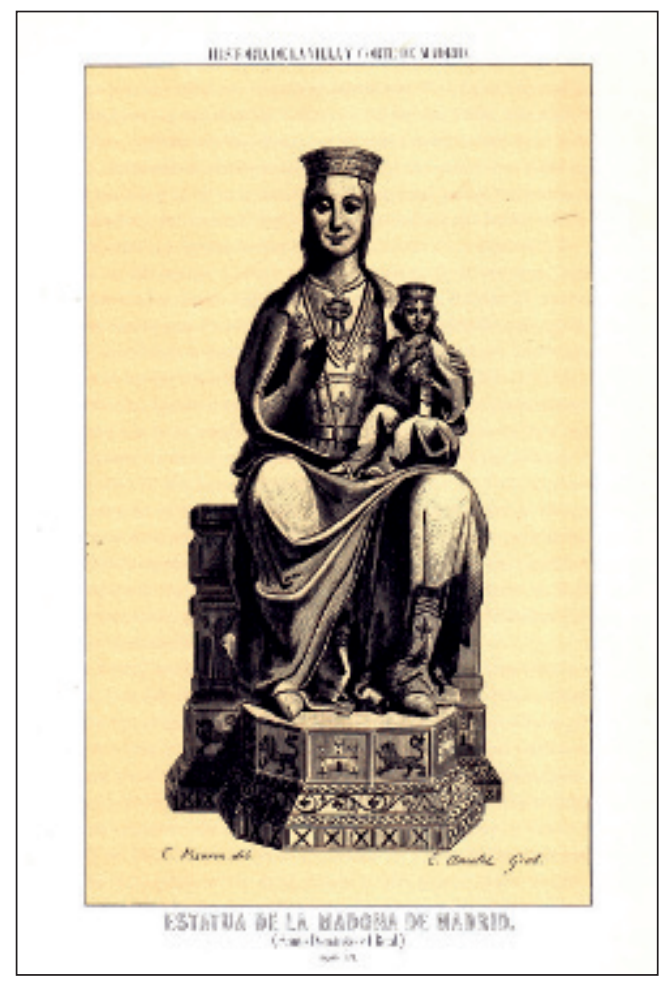

Fig. 1. Madona de Madrid, 1861. Dibujo de Cecilio Pizarro y grabado de Emilio Ancelet.

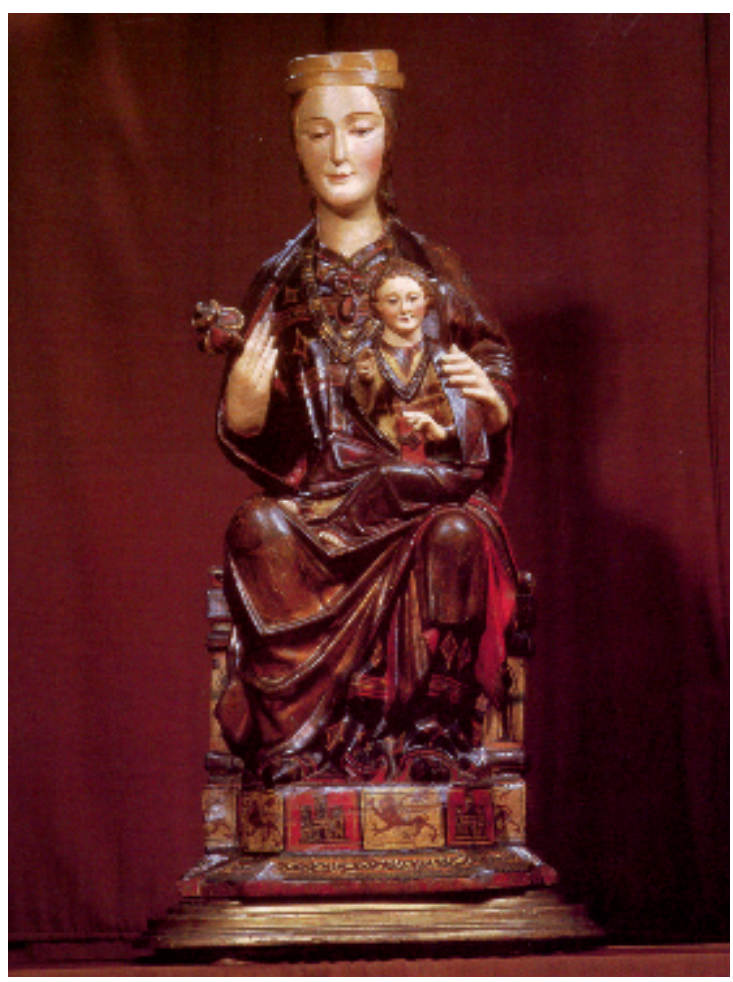

Fig. 2. Madona de Madrid. Santo Domingo el Real de Madrid.

Santo Domingo, en cambio, por sus recuerdos históricos, por la enseñanza artística que alguno de sus miembros arquitectónicos ofrece como precioso ejemplo del estilo mudéjar, por las pinturas que encierra, y por los monumentos arqueológicos que guarda en su recinto, bien merece la acertada excepción que en su favor se ha hecho, en esta capital, donde tanto escasean los monumentos de las pasadas edades, elocuentes páginas con que va escribiendo el arte su historia sobre la superficie de la tierra"2.

Juan de Dios de la Rada y Delgado escribió las líneas arriba recogidas en 1869. Ese mismo año, el convento femenino de Santo Domingo el Real de Madrid, fundado en 1219, fue demoli$\mathrm{do}^{3}$. Algunas piezas procedentes de este se conservan hoy en el Museo Arqueológico Nacional, habiendo sido otras depositadas en el actual convento de Santo Domingo el Real de Madrid. Entre las imágenes que se custodian en la clausura de este último se encuentra la denominada Madona de Madrid, dada a conocer en 1861 por José Amador de los Ríos, quien, en su Historia de la Villa y Corte de Madrid incluye un grabado de la imagen, de excesivo carácter interpreta-

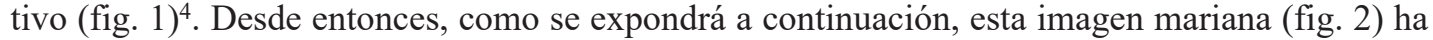
sido atribuida a diversos monarcas castellanos como consecuencia de los castillos y leones que decoran la peana de la imagen, así como a determinados personajes próximos a la corona, atribuyéndole una cronología que abarca desde 1219 hasta 1478 .

\footnotetext{
2 Rada y Delgado, 1869: 223.

3 Romero, 2008: 35; Estella, 1978: 59; Real, 2011: 55.

${ }^{4}$ Amador de los Ríos, 1978: 341.
} 


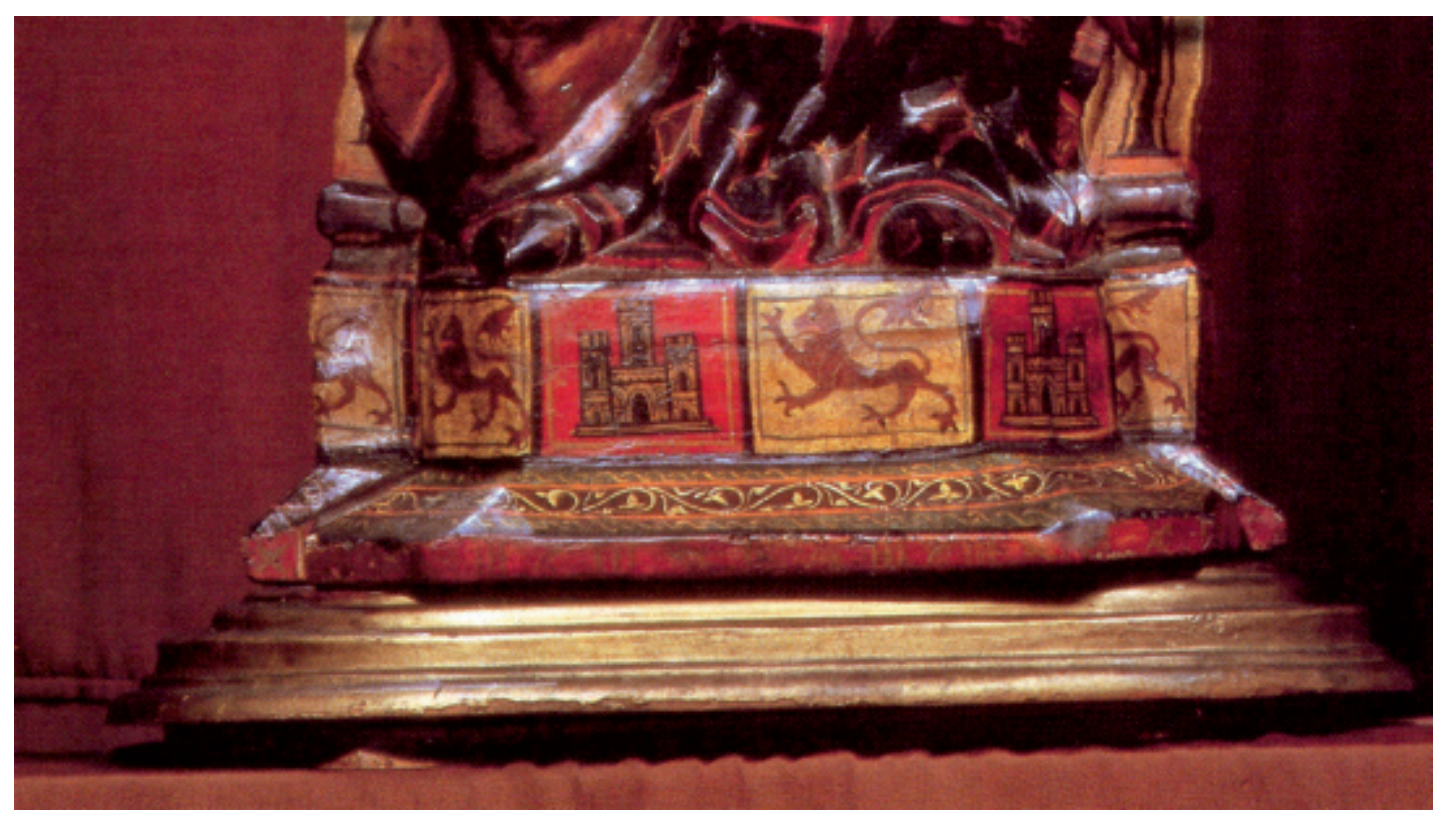

Fig. 3. Detalle de los castillos y leones que decoran la peana. Madona de Madrid. Santo Domingo el Real de Madrid.

Por lo tanto, ante la necesidad de precisar la datación de la imagen y de identificar al donante, en el presente artículo se analizarán las aportaciones de los autores que se han aproximado a su estudio, con especial atención a la contribución de Clara Fernández-Ladreda, quien fecha esta imagen en el último tercio del siglo XIII. A la luz de los privilegios y demás mercedes reales concedidos al convento durante ese período de tiempo, se planteará la hipótesis de que se trate, en realidad, de una donación de Sancho IV (1284-1295), quien, hasta el momento, no había sido relacionado con la Madona de Madrid. Y, por último, con la intención de precisar, aún más, la cronología de la imagen, se examinarán las semejanzas existentes entre la Virgen de Santo Domingo el Real de Madrid y la del monasterio de Cañas (La Rioja), proponiendo para esta última una nueva comitente.

\section{Una Virgen y demasiados donantes}

La tradición conventual remonta el origen de la Virgen a la propia fundación del cenobio, habiendo sido, por lo tanto, una donación de santo Domingo de Guzmán (1170-1221) , hecho que, sin embargo, no explicaría la presencia de las armas reales en la peana de la imagen (fig. 3). Si bien es cierto que se conocen piezas decoradas con castillos y leones que no parecen guardar relación alguna con la realeza castellana, en el caso concreto de la Madona de Madrid, debido al patronazgo regio del que gozó el monasterio de Santo Domingo el Real de Madrid desde su fundación, la donación real parece presentarse como la hipótesis más razonable ${ }^{6}$.

Entre los monarcas castellanos que la historiografía ha relacionado con la Madona de Madrid destaca, en primer lugar, Fernando III (1217-1252), quien el 23 de junio de 1228 tomó bajo su

\footnotetext{
5 Alonso, 1919: 19; Pérez, 2011: 928.

${ }^{6}$ Menéndez, 1991: 91; Bango, 2001: 64; Nogales, 2009: vol. I, 42-43, nota 61.
} 
encomienda y "defendimiento" al convento madrileño, al que favoreció con numerosos privilegios y donaciones? ${ }^{7}$. En efecto, la estrecha relación que este rey parece haber mantenido con la comunidad de Santo Domingo el Real de Madrid lo convertiría, aparentemente, en uno de los posibles responsables del encargo de la talla y su posterior entrega al convento madrileño ${ }^{8}$. Además, según el anónimo autor de los apuntes que sirvieron para redactar el oficio en el que la Real Academia de la Historia instaba al ministro de la Gobernación en la conservación del monasterio de Santo Domingo el Real de Madrid, la imagen mariana dataría del siglo XIII ${ }^{9}$, cronología compatible, en principio, con el posible patronazgo de Fernando III, aunque resulta una datación excesivamente amplia, que merece ser precisada.

Sin embargo, otros autores retrasan considerablemente la fecha de ejecución de la Madona de Madrid. Juan de Dios de la Rada y Delgado menciona la existencia de una imagen mariana de madera, custodiada por la comunidad de religiosas, que fecha en el siglo XIV y que, según el autor, podría tratarse de una donación de Pedro I de Castilla (1350-1369) ${ }^{10}$. Gracias al testimonio de De la Rada y Delgado sabemos, además, que la Madona de Madrid estuvo previamente "en un retablo de la sala del capítulo"11. Amador de los Ríos, quien vio la imagen colocada ya en el coro, apunta nuevamente a Pedro I como comitente de la Madona de Madrid, haciendo extensible el posible encargo y posterior donación de la imagen a Enrique II (1369-1379) ${ }^{12}$, hipótesis de la que se hace eco Isidoro Rosell y Torres. Este último asegura que los castillos y leones que decoran la peana de la Virgen son "idénticos con la forma en que se ven grabados en los sellos de plomo que penden de los privilegios y cartas del rey Don Pedro y de su hermano Don Enrique", a lo que añade que "los adornos ó grecas que corren horizontalmente en el pie ó peana de la silla y por bajo de dichos castillos y leones alternados, son del mismo gusto que se observa en las menudas y delicadas labores que encuadran el sello rodado del rey Don Pedro en privilegios concedidos á Madrid"13. Asimismo, plantea la posibilidad de que se trate de una donación de algún familiar de los mencionados monarcas ${ }^{14}$.

Por su parte, Julio Real González considera que se trata de una obra realizada en pleno siglo XV, lo que le lleva a señalar a sor Constanza de Castilla — nieta de Pedro I y priora del convento madrileño entre 1415 y $1465^{15}$ — como posible donante de la misma ${ }^{16}$, si bien no es el escudo de los Castilla el que decora la imagen, el cual sí aparece, por ejemplo, en el sepulcro de la religiosa conservado en el Museo Arqueológico Nacional. Más recientemente, Mercedes Pérez Vidal ha señalado la presencia de esta imagen en el dormitorio de las religiosas, "ante el cual estas rezaban diariamente el oficio de Nuestra Señora", destacando su carácter procesional. Según indica Pérez Vidal, con motivo de la festividad de la Natividad de la Virgen, la imagen era adornada por las religiosas, quienes acudían a su capilla a rezar el Rosario. Puesto que el objetivo de su artículo es otro, Mercedes Pérez Vidal no profundiza en la datación de la imagen, limitándose a afirmar que esta ha sido datada a mediados del siglo XIV ${ }^{17}$.

\footnotetext{
7 Sabemos, además, que fray Domingo de Segovia, confesor de Fernando III, llegó a ser prior de Santo Domingo el Real de Madrid. Como tal está documentado en 1259. Alonso, 1919: 19; Huarte, 1925: 6; Romero, 2008: 53 y 127.

8 Vicente, 1986: 102.

9 González, 2005: 86

10 Rada y Delgado, 1869b: 286.

11 Rada y Delgado, 1869b: 285.

12 Amador de los Ríos, 1861: 363, nota 4.

13 Los castillos que decoran la peana presentan sencillos volúmenes, propios de las representaciones heráldicas castellanas del siglo XIII, y, por lo tanto, anteriores a la cronología propuesta por Rosell y Torres. No obstante, la datación de este tipo de imágenes escultóricas a través de las formas heráldicas que las acompañan resulta arriesgado, al poder haber sido estas, objeto de posteriores repintes que hayan podido alterar su aspecto original. Por este motivo, consideramos necesario completar dicho análisis con un estudio formal y tipológico de la pieza en cuestión. Pardo, 1987: 73; Menéndez, 2004: 77 y 86.

14 Rosell, 1875: 172-173.

15 Alonso, 1919: 132.

16 Real, 2011: 62.

17 Pérez, 2011: 928.
} 
A pesar del evidente interés de los trabajos arriba reseñados, la aportación de mayor relevancia para el estudio de la Madona de Madrid es la de Clara Fernández-Ladreda, quien en 1989 realizó un profundo análisis de la imaginería mariana navarra en la Edad Media, el cual nos sirve para disipar todo género de dudas con respecto a la correcta datación de la imagen que nos ocupa. Entre las Vírgenes góticas navarras, la autora incluye el tipo que ella misma denomina "vasco-navarro-riojano". Las obras integradas en este constituyen el conjunto más importante en Navarra en época bajomedieval, aunque, si bien resultan características de la mencionada región ${ }^{18}$, no son exclusivas de esta, habiéndose podido documentar algunos ejemplos fuera de dicha área geográfica $^{19}$, entre los que, como veremos, se encontraría la propia Madona de Madrid²0.

\section{Las Vírgenes vasco-navarro-riojanas y la Madona de Madrid}

Las imágenes incluidas por Clara Fernández-Ladreda en el tipo vasco-navarro-riojano responden a unas características que se repiten

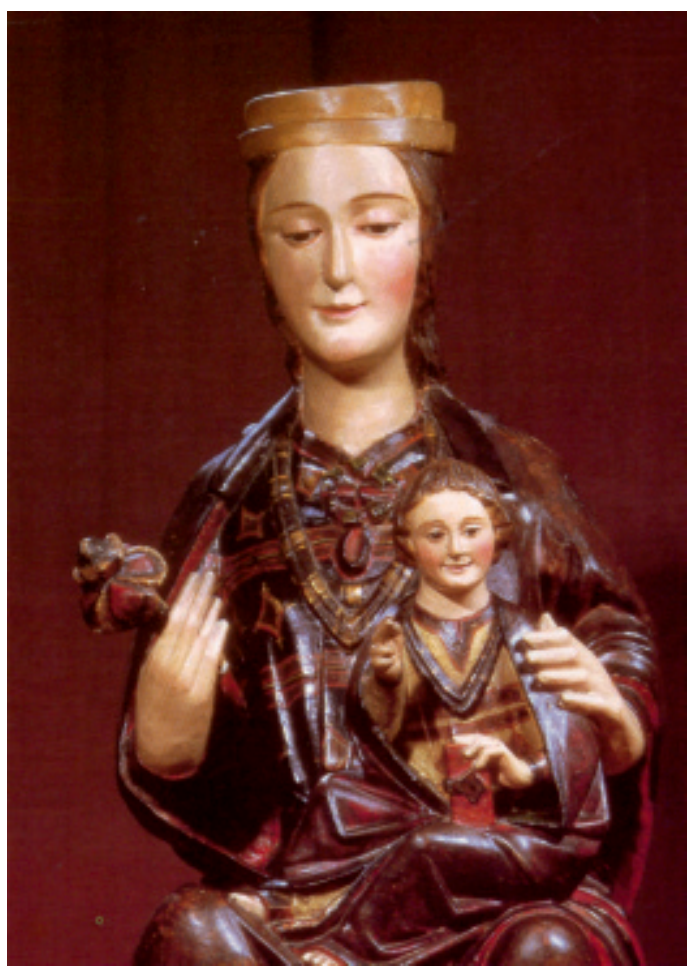

Fig. 4. Detalle de la Virgen y el Niño. Madona de Madrid. Santo Domingo el Real de Madrid. en todas y cada una de ellas, y que están presentes en la Madona de Madrid. María, en posición frontal, apoya, generalmente, su mano izquierda sobre el hombro o brazo del Niño. En la mano derecha, la cual presenta elevada, suele llevar o bien una flor, o bien una poma. El Niño, sedente sobre la pierna izquierda de la Madre, rompe la frontalidad del conjunto al aparecer ligeramente girado hacia la derecha, bendiciendo con la diestra. En la mano izquierda sujeta, en algunas ocasiones, un libro, y, en otras, una esfera. Al menos uno de los pies los presenta apoyados en el regazo materno, o sobre la pierna derecha de su Madre (fig. 4).

En lo que respecta a la indumentaria, la Virgen cubre su cabello con un velo que cae sobre los hombros y la espalda, y sobre el cual se coloca una corona ${ }^{21}$. Viste una túnica larga, ajustada a la cintura con un ceñidor de correa. El escote es redondo y se cierra con un broche circular que en ocasiones adopta forma floral ${ }^{22}$. Encima lleva un manto con un fiador triangular que se ajusta al brazo derecho y cae sobre el izquierdo. El calzado, puntiagudo, asoma por debajo de la túnica. El atuendo del Niño se reduce a un manto, similar al de su Madre, con un fiador triangular, y una túnica ${ }^{23}$.

18 Fernández-Ladreda, 1989: 141.

19 Fernández-Ladreda, 1989: 147: "Sobre la base de las entidades provinciales nos encontramos que el ámbito geográfico del tipo Vasco-navarro-riojano abarcaría el País Vasco, Navarra, La Rioja, parte de Castilla — provincias de Palencia, Valladolid, León, Santander y Madrid - y parte de Aragón — provincias de Zaragoza y Huesca-”. Véase también Ara, 1977: 138-142.

20 Fernández-Ladreda, 1989: 146, nota 19.

${ }^{21}$ En el caso concreto de la Madona de Madrid, esta ha perdido tanto el velo como la corona, los cuales habrían sido tallados en piezas independientes, aumentando la fragilidad de las mismas.

22 Bernis, 1970: 208.

${ }^{23}$ Fernández-Ladreda, 1989: 142. 
Desde el punto de vista de la geografía eclesiástica, el tipo vasco-navarro-riojano parece circunscribirse a la diócesis de Calahorra-La Calzada, hallándose La Rioja en una posición preeminente respecto a Navarra y País Vasco ${ }^{24}$. En relación a la cronología, la mencionada autora distingue, dentro del tipo, tres grupos o variantes, incluyendo a la Madona de Madrid en el "primer grupo del tipo vasco-navarro-riojano en sentido estricto", del cual forman también parte, dentro del ámbito navarro, las Vírgenes de Los Arcos, Miranda de Arga, Arizaleta, Fitero, Berbinzana, Mendigorría, Artaza y Ubago ${ }^{25}$. Todas ellas se caracterizan por la postura del Niño que apoya su pie derecho sobre la pierna derecha de su Madre, y el izquierdo, sobre el regazo de esta; la forma apuntada de ambos fiadores, el predominio del plegado anguloso, especialmente visible en el borde del velo y la parte inferior del manto, la flor que porta María en su mano derecha y el libro cerrado que sujeta Jesús ${ }^{26}$.

Fernández-Ladreda, corrigiendo a los autores que le habían precedido en el estudio de la imaginería mariana navarra, data esta variante del tipo vasco-navarro-riojano en el último tercio del siglo XIII ${ }^{27}$. Por lo tanto, la Madona de Madrid tuvo que ser realizada en las últimas tres décadas del siglo XIII, dato que nos permite, en primer lugar, descartar a santo Domingo de Guzmán, Fernando III, Pedro I, Enrique II y sor Constanza de Castilla como posibles donantes de la pieza, y, en segundo lugar, apuntar hacia los monarcas que ocuparon el trono castellano durante esos años: Alfonso X (1252-1284), Sancho IV (1284-1295) y Fernando IV (1295-1312).

\section{El patronazgo regio del monasterio de Santo Domingo el Real de Madrid en el último tercio del siglo XIII}

Como se ha señalado con anterioridad, desde el 23 de junio de 1228, el monasterio de Santo Domingo el Real de Madrid quedó bajo la encomienda de Fernando III, protección que le fue confirmada por los sucesivos monarcas ${ }^{28}$. Alfonso X lo hizo en 1258 y 1272, Sancho IV en 1282 y Fernando IV en 1301. En este sentido cabe destacar, según ha señalado Juan Ramón Romero Fernández-Pacheco, que entre 1228 y 1330 las cartas de encomienda y defensa del convento expedidas por la cancillería supusieron "un compromiso privado de los reyes con el convento madrileño actuando de aquel modo como verdaderos encomenderos". Por el contrario, a partir del reinado de Pedro I, "esa protección fue más bien un compromiso protocolario del Rey como institución pública no muy diferente de aquellos otros compromisos adoptados con la mayoría de conventos y monasterios castellanos" 29 .

El primer juro poseído por el convento madrileño le fue dado en 1269 por Alfonso X, quien le concedió una renta a cuenta de la regalía de la sal de Atienza. Años más tarde, Alfonso X defendió el derecho de la comunidad de religiosas de Santo Domingo el Real de Madrid a administrar sus patrimonios personales y heredades, después de que Gregorio IX pidiese a Fernando III que no restringiese el crecimiento patrimonial de los cenobios y, en especial, el del convento dominico de Madrid, el cual tenía autorizado un dominio territorial no superior a seis yugadas, a la vez que solicitaba al monarca que permitiese al convento subsumir los bienes de las monjas que falleciesen en clausura ${ }^{30}$.

El 7 de marzo de 1270 Alfonso X permitió a las dueñas del convento vender su patrimonio, al proceder muchas de ellas de lugares lejanos. Hasta entonces, para ello, era necesario que hubiesen transcurrido, al menos, dos años desde su profesión. Asimismo, gracias a una carta de

\footnotetext{
24 Fernández-Ladreda, 1989: 149-150.

25 No obstante, al igual que el tipo vasco-navarro-riojano no era exclusivo de este ámbito geográfico, el primer grupo o variante del mismo tampoco lo es: Fernández-Ladreda, 1989: 151-152.

${ }^{26}$ Fernández-Ladreda, 1989: 150.

27 Fernández-Ladreda, 1989: 151.

28 Pérez de Tudela, 1985: 992 y 1004.

29 Romero, 2008: 152.

30 Romero, 2008: 46 y 443.
} 
merced del rey fechada en 1270, sabemos que el convento estaba exento de todo tipo de portazgo o recargo que gravase el tránsito de todas sus mercancías de abastecimiento, fundamentalmente hierro, madera, pescado, lana y paños, procedentes de la ciudad y arzobispado de Toledo ${ }^{31}$.

A Alfonso X y, muy especialmente, a su esposa Violante, se debería, asimismo, la culminación de las obras del primer edificio conventual, iniciadas hacia 1257 y concluidas en fecha anterior al año 1272. Ese mismo año, Alfonso X cedió al convento algunos aprovechamientos del Monte del Manzanares, patrimonio privado del monarca. Desde el 12 de enero de 1272 los ganados del convento madrileño pudieron andar libres y seguros por todo el reino, exentos del pago de montazgos, diezmos, rentas o servicios, gracias al favor del monarca. Además, sus pastores quedaron libres de pagar el quinto en el territorio de las órdenes militares y el portazgo de las mercancías que transportasen y que fuesen propiedad del convento, del embargo de cualquier bien perteneciente a la institución, de las multas o tributos por recoger leña para cocer pan y corteza para el calzado, e incluso del pago de portazgo por las cosas propias que llevasen a sus cabañas o por la ropa para su vestido ${ }^{32}$. Sancho IV confirmó dicha exención el 26 de noviembre de $1284^{33}$. El convento contaba asimismo desde, al menos, 1291, con un "mayordomo", encargado de "recibir" y "ver" los ganados del convento. Este "mayordomo" era, además, uno de los excusados del cenobio, merced real que fue confirmada por Fernando IV, Alfonso XI y Pedro I ${ }^{34}$.

El 29 de noviembre de 1284 Sancho IV, a imitación de su abuelo, acogió al convento bajo su protección, confirmando todos los privilegios otorgados anteriormente por pontífices, monarcas e infantes: "Por fazer bien e merced a las duennas del monesterio de Santo Domingo de Madrit e porque rueguen a Dios por nos, recebímoslas en nuestra guarda e en nuestra comienda e en nuestro defendimiento, a ellas e a los frayres que y fueren e a todas sus cosas" 35 . En 1285 las dueñas de Santo Domingo el Real de Madrid recibieron, además, el privilegio de estar aforadas y exentas de la jurisdicción laica ${ }^{36}$, junto con el derecho a la percepción de sus respectivas herencias y la autorización para enterrar en el monasterio ${ }^{37}$. En palabras de Juan Ramón Romero Fernández-Pacheco, Sancho IV convirtió el convento en "una ínsula jurisdiccional de la que los primeros y principales beneficiarios eran las monjas profesas, cuya exención a título personal de la justicia laica fue consustancial con su estado de religión"38.

Durante el reinado de Fernando IV, se recurrió a Benedicto XI para que sancionase el derecho del convento a conservar los privilegios reales y se confirmaron estos, acogiendo al convento bajo su encomienda, al igual que hicieron sus antecesores, el 6 de noviembre de 1301. Años más tarde, el 28 de febrero de 1309, Fernando IV, atendiendo una petición del convento, dio su autorización para que este pudiese "çerrar una calleja que es entre la lavor nueva de su monesterio e las sus casas que son enfruente de la dicha obra, en la collaçión de Sant Martín, e porque aquella calleja non enbarga a ninguna cosa del Conçejo [...] tengo por bien e mando que la çierren de tapia e de argamasa, qual ellos más quisieren, en esta guisa: desde la espina de las sus casas de la calle que va a Sant Martín, fasta el espina de las casas que fueron de Roy Martínez, vicario que fue" 39 .

Ante los datos expuestos, cualquiera de los tres monarcas mencionados podría haber donado la imagen mariana objeto de estudio al convento de Santo Domingo el Real de Madrid, si bien la relación que mantuvieron Alfonso X y Sancho IV con las dueñas habría sido más estrecha que la de Fernando IV, quien se habría limitado, en gran medida, a confirmar los privilegios que sus

31 Romero, 2008: 192-193 y 488.

32 Romero, 2008: 166, 177, 237-238, 248, 379, 392 у 487.

33 Carrasco, 1994: doc. 3, 20-26.

34 Romero, 2008: 372-373.

35 Carrasco, 1994: 30-32.

36 Romero, 2008: 108.

37 Pérez de Tudela, 1985: 1009.

38 Romero, 2008: 108.

39 Carrasco, 1994: vol. II, docs. 30, 34, 35, 37, 41-44, 47, 90-93, 100-107, 110-114, 120-127 y 131-134; Romero, 2008: 256. 
antecesores habían concedido al cenobio. A pesar de ello, sí que parece factible decantarse por un posible donante a la luz de la "vertiginosa actividad administrativa" del convento madrileño durante los primeros años del reinado de Sancho IV. Si bien Juan Ramón Romero FernándezPacheco atribuye esta situación a la "extrema debilidad política del monarca" ${ }^{40}$, quizás el hecho de que de las treinta y nueve veces que la comunidad acudió a la cancillería desde su fundación hasta 1305 , veinte ${ }^{41}$ de ellas tuviesen lugar durante el reinado de Sancho $\mathrm{IV}^{42}$, podría deberse a la estrecha relación que el convento mantuvo con el monarca, así como a la mayor protección que las dueñas habrían recibido por parte de este.

Cabe asimismo recordar que el 10 de junio de 1285, Sancho IV concedió al convento de Santo Domingo el Real de Madrid la exención general de portazgo de todo el reino y del pago de cancillería por las cartas y documentos que pudiese necesitar. Esto explicaría esa "vertiginosa actividad administrativa" 43 y pondría de manifiesto, una vez más, la importante labor de patronazgo desempeñada por el monarca quien, en este mismo documento, acoge nuevamente al convento y todos sus bienes bajo la protección de la corona, declarando, con ello, la inviolabilidad de los mismos ${ }^{44}$.

De hecho, la relación del monarca con el convento madrileño habría sido anterior a su ascenso al trono, como lo demuestra una carta de encomienda fechada en 1282 - año en el que se sublevó contra su padre, reclamando plenos derechos absolutos sobre el trono y provocando con ello una situación de guerra civil${ }^{45}$ - , por la cual, el todavía infante Sancho, puso bajo su protección al convento madrileño, documento al que habría que sumar, al menos, tres confirmaciones de privilegios expedidas ese mismo año ${ }^{46}$.

En efecto, la hipótesis de que la Madona de Madrid sea, en realidad, una donación de Sancho IV cobra mayor peso al examinar el patronazgo artístico tanto de este monarca castellano como de su más estrecho círculo cortesano ${ }^{47}$.

40 Romero, 2008: 521.

${ }^{41}$ Se trata de un número solo superado durante el reinado de Isabel I (23 ocasiones): Romero, 2008: 522.

42 Romero, 2008: 522.

43 Pérez de Tudela, 1985: 1009.

44 Carrasco, 1994: vol. II, doc. 12, 45-52.

45 Nieto, 2014: 37-38.

46 Esta iniciativa se podría igualmente relacionar con el dominicanismo de Sancho IV y María de Molina. Sabemos que cuando todavía era infante, Sancho IV otorgó a los dominicos un amplio privilegio que vinculaba la corona al éxito de la Orden, cumpliendo así con los deseos de su madre. Muchos de los privilegios que Sancho IV y María de Molina concedieron a la Orden de Predicadores durante su reinado habrían sido en agradecimiento por los servicios que los frailes dominicos habían realizado a favor de los monarcas, llegando incluso a falsificar en 1292 una bula papal de dispensa para subsanar su matrimonio no canónico. Véase Moreta, 1996: 182-184; Domínguez, 2003: 13-25; Romero, 2008: 570; Royer, 2010: 483-484 y 486; Nieva, 2011: 24-25, nota 27.

47 Se conservan, al menos, otras dos Vírgenes con Niño del tipo vasco-navarro-riojano con castillos y leones en la peana: la Virgen de los Remedios de Urrialdo (Mártioda, Álava) y la Virgen Blanca de Tuesta (Valdegovía, Álava), la cual presenta escudos cuartelados. Lamentablemente, se desconoce la identidad de sus respectivos comitentes: López, 1982: 150 y 216; Tabar, 2007: 236-239. En el caso concreto de la Virgen de Tuesta, esta ha sido relacionada estilísticamente con la Virgen de la Rosa, fechada a finales del siglo XIII o principios del siglo XIV, conservada actualmente en la cueva de la iglesia del monasterio de Santa María la Real de Nájera y procedente de la capilla del castillo o palacio real, edificio situado en las actuales eras del castillo, sobre el cementerio viejo. Este alcázar habría sido edificado en el siglo XIII, hallándose en ruinas en la segunda mitad el siglo XVIII, momento en el que la denominada Virgen de la Rosa pudo haber sido trasladada a la iglesia de San Jaime. En 1845, al amenazar ruina la mencionada iglesia, la imagen habría sido llevada al monasterio que, por aquel entonces, se encontraba bajo el decreto de desamortización de 1835: Sáez, 2000: 167; Martiarena, 2001: 214 y 217. Durante la restauración de la Virgen de la Rosa se documentó la presencia de dos lipsanotecas en el sitial de la Virgen: Martiarena, 2001: 218; Fresneda, 2012: 180. Este hallazgo pondría de manifiesto el posible uso de estas Vírgenes a modo de imagen-relicario. En el caso de la Madona de Madrid sería interesante poder comprobar si en su sitial existe o no el mismo orificio que en el caso de la Virgen de Nájera. Lamentablemente, el examen directo de la imagen madrileña resulta prácticamente imposible al custodiarse en clausura, si bien es cierto que la imagen fue expuesta en 1986 con motivo del primer centenario de la diócesis de Madrid-Alcalá y en el catálogo publicado no se menciona nada al respecto: Vicente, 1986: 102. 
Fig. 5. Privilegio rodado por el que Sancho IV dispone ser enterrado en la catedral de Toledo. Archivo Histórico Nacional, Clero, carpeta 3022, núm. 5 bis. Detalle de la miniatura. Reproducido en Fernando Gutiérrez Baños, Las empresas artísticas de Sancho IV el Bravo, Junta de Castilla y León, Consejería de Educación y Cultura, Burgos, 1997, p. 282.

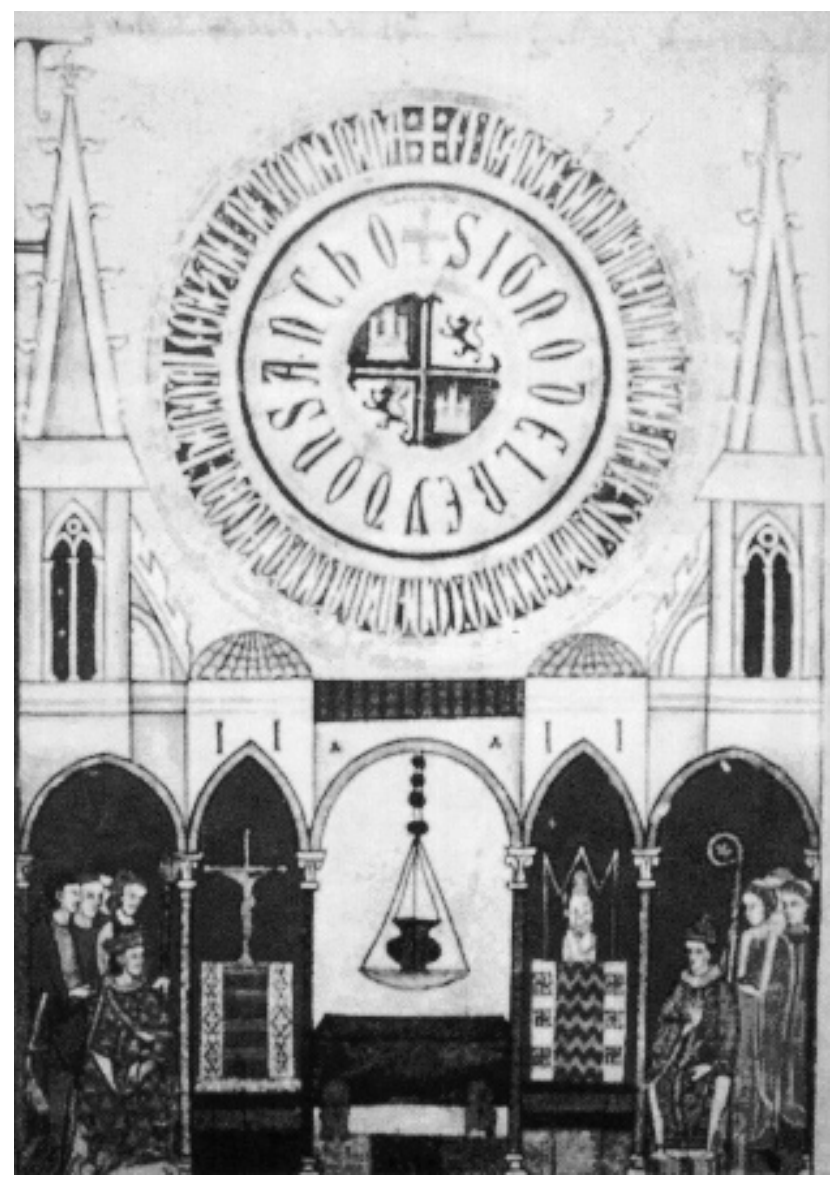

\section{¿Una donación de Sancho IV?}

Como ha apuntado Fernando Gutiérrez Baños, la devoción mariana del monarca, así como la de su entorno más inmediato, queda puesta de manifiesto, no solo en las Cantigas de Alfonso X el Sabio, sino también en las obras de su preceptor, fray Juan Gil de Zamora. Especial interés presenta, en este sentido, la miniatura que decora el privilegio rodado fechado en 1285 en el que Sancho IV dispuso ser enterrado en la catedral de Toledo. En él, el monarca aparece representado junto a un altar de Santa María, devoción en la que se incide en el propio texto, en el que el rey afirma tener a la Virgen por "sennora e por auogada en todos nuestros fechos y cuyo siervo somos quitamientre, e de quien siempre recibiemos muchos bienes e granadas merçedes e atendemos reçebir" (fig. 5) ${ }^{48}$.

Tres fueron los santuarios marianos con los que Sancho IV mantuvo mayor relación: Villalcázar de Sirga ${ }^{49}$, La Vid y La Hiniesta, resultando de especial interés para el tema que nos ocupa, el segundo de estos, en el que se conserva la imagen de Nuestra Señora de la Vid, fechada bien

48 Gutiérrez, 1997: 113-114; (2001): 258.

49 La Virgen de Villalcázar de Sirga se conoce como Santa María la Blanca o Virgen de las Cantigas ya que habría servido de inspiración al rey don Alfonso X para la composición de las Cantigas de Santa María: Fresneda, 2012: 182-183. 


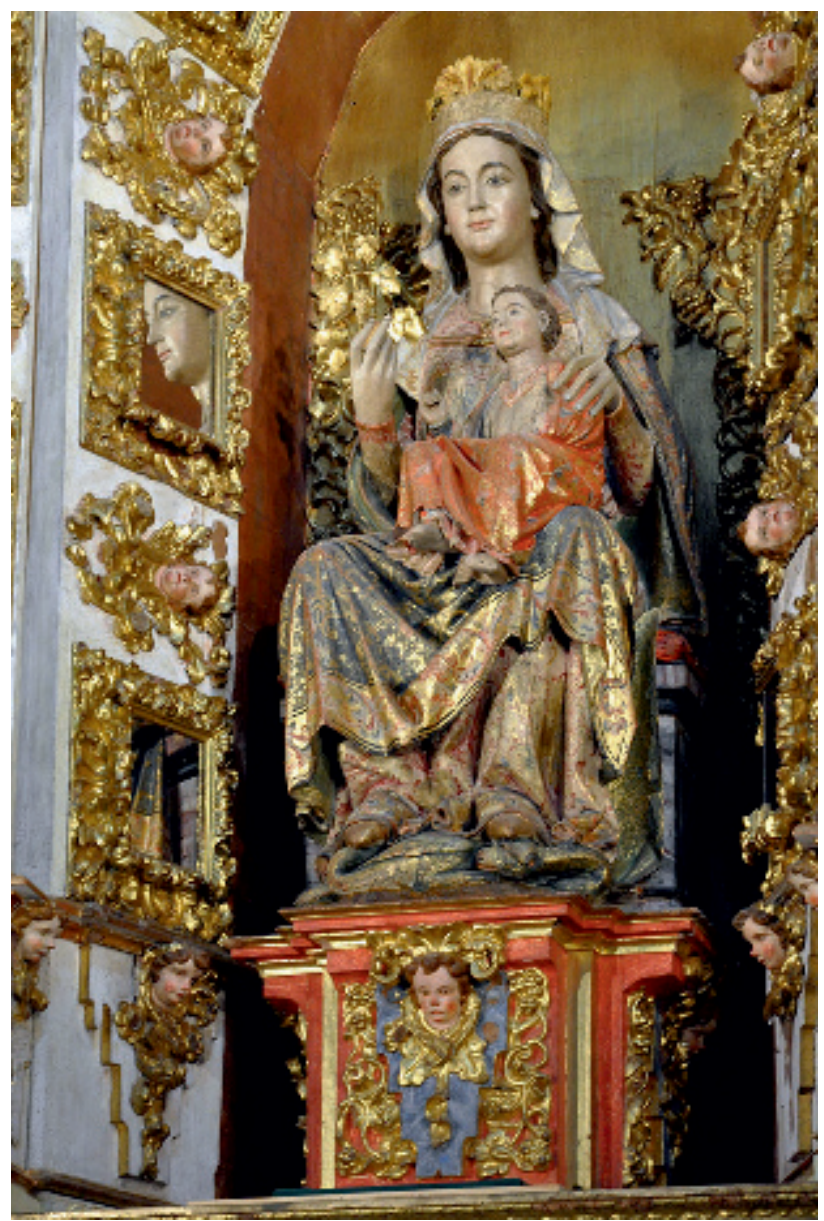

Fig. 6. Nuestra Señora de la Vid.

Monasterio de Santa María de La Vid (Burgos).

a finales del siglo XIII ${ }^{50}$, bien hacia $1300^{51}$ (fig. 6). Tanto María Martínez Martínez como Fernando Gutiérrez Baños afirman que se trataría de una donación de Sancho IV. Ambos autores adscriben, además, la imagen al tipo vasco-navarro-riojano, lo que incluiría a Burgos entre las provincias en las que se han conservado ejemplos de este modelo mariano ${ }^{52}$. De hecho, Fernández-Ladreda ha señalado la posibilidad de que el origen del tipo vasco-navarro-riojano sea, en realidad, burgalés, acaso ligado a los talleres de la catedral ${ }^{53}$.

Si bien la policromía que luce actualmente Nuestra Señora de la Vid data del siglo XVIII, gracias al testimonio del siglo XVII de fray Bernardo de León, sabemos que las armas reales habrían estado en origen presentes, entre otros muebles, en el retablo del altar mayor, en el cual, según el libro becerro del monasterio, "estava collocada nuestra madre y patrona y titular Santa María de La Vid"54. Gutiérrez Baños señala, además, la vigencia del tipo vasco-navarro-riojano en el entorno personal de Sancho IV, como lo atestiguaría la iconografía mariana de las Cantigas y, más concretamente, del mencionado privilegio rodado de 1285, en el que "el monarca dispuso ser enterrado en la catedral de Toledo, donde se dibujó de manera deliciosa y vivaz una imagen

\footnotetext{
50 Gutiérrez, 1997: 117 y 119.

51 Martínez, 1991: 150.

52 Martínez, 1991: 151; Gutiérrez, 1997: 117.

53 Fernández-Ladreda, 2001: 416.

54 Gutiérrez, 2001: 286, nota 98.
} 
Fig. 7. Virgen de la Barda. Parroquia de Santa María la Real de Fitero (Navarra).

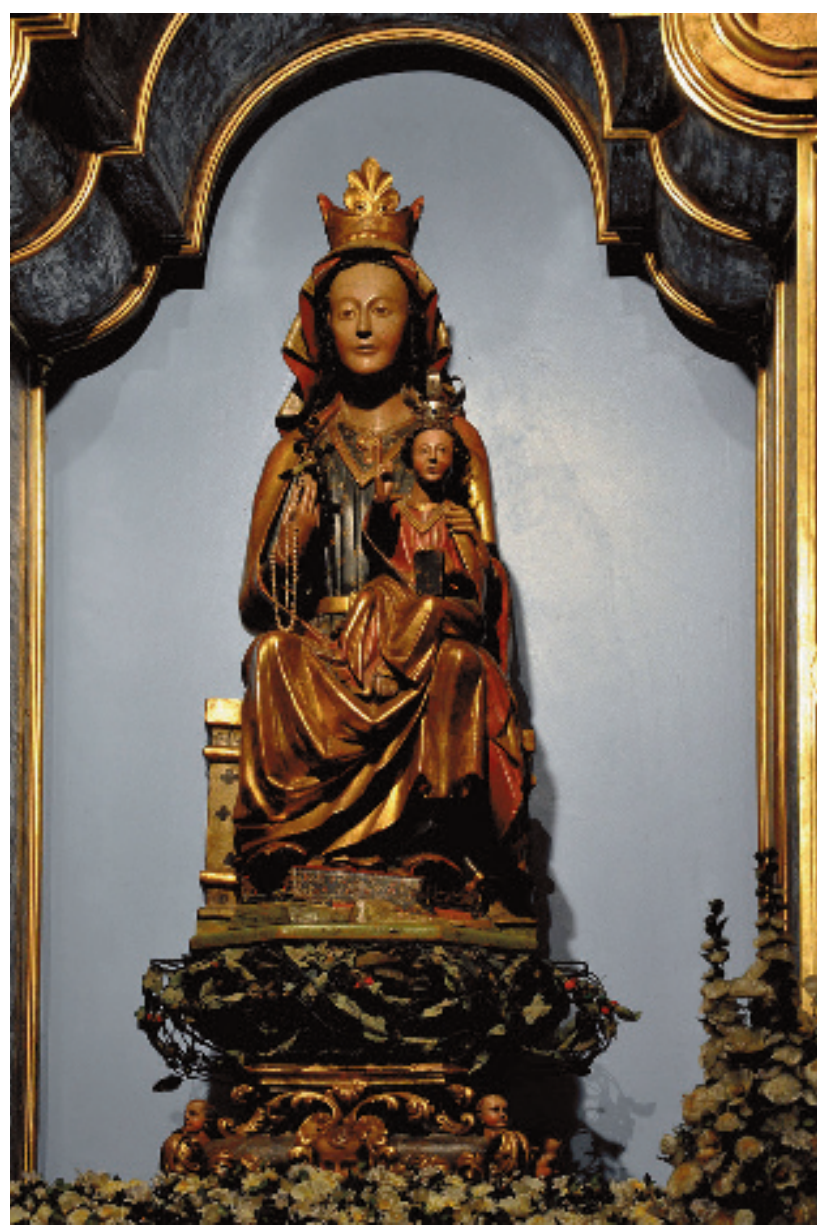

de la Virgen con el Niño plenamente identificable con el tipo vasco-navarro-riojano, salvando el que ambas figuras no llevan manto, suprimido tal vez en aras de una simplificación del dibujo" 55 .

Según Gutiérrez Baños, "el carácter familiar del tipo en el entorno de la corte, lo ajeno del mismo en el entorno del monasterio de La Vid y la exquisita calidad de la imagen permiten sostener la hipótesis de que Nuestra Señora de la Vid se debió a la munificencia de Sancho IV, que de esta manera dotó de una imagen a su gusto a uno de los lugares que solía frecuentar" 56 . Al tipo vasco-navarro-riojano pertenecerían también las Vírgenes con Niño conservadas en la iglesia de Villalcázar de Sirga, de sobra conocidas por Sancho IV ${ }^{57}$.

Clara Fernández-Ladreda apunta asimismo la posibilidad de que la Virgen de la Barda de Fitero sea una donación realizada por un miembro del séquito de Sancho IV en 1285, con motivo de la visita realizada por el monarca al monasterio de Fitero, coincidiendo con la culminación de las obras del recinto amurallado que rodea el monasterio ${ }^{58}$, lo que indicaría el éxito del que gozó esta tipología mariana en el entorno más cercano del monarca (fig. 7). A pesar de que Javier Martínez de Aguirre y Faustino Menéndez Pidal señalan la imposibilidad de identificar correctamente los mutilados escudos de la peana - aparentemente escudos con siete u ocho bezantes de

55 Gutiérrez, 1997: 120.

56 Gutiérrez, 1997: 122; 2001: 284-286.

57 Gutiérrez, 1997: 120.

58 Fernández-Ladreda, 1988: 153-154; Gutiérrez, 1997: 120. 


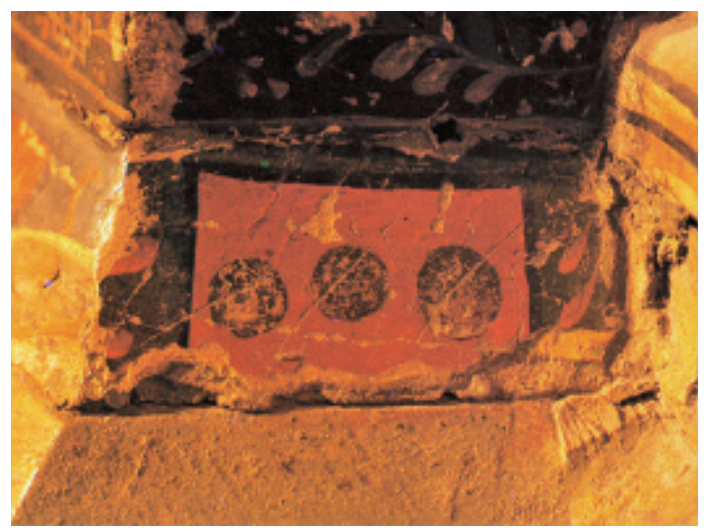

Fig. 8. Detalle de los escudos en la peana de la Virgen de la Barda. Parroquia de Santa María la Real de Fitero (Navarra).

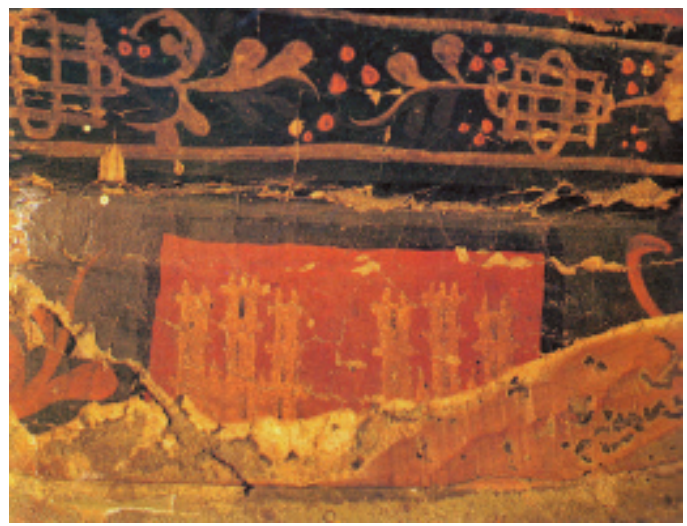

Fig. 9. Virgen de la Barda. Parroquia de Santa María la Real de Fitero (Navarra). Detalle de los escudos en la peana.

plata en campo de gules que alternan con escudos con tres castillos en campo de gules-, afirman que "los dos castillos [conservados en los escudos de la peana] excluyen la posibilidad de que sean armas reales, pero avalan la hipótesis de armerías castellanas, donde tuvieron gran difusión" (figs. 8 y 9$)^{59}$.

En lo que respecta a la cronología de la imagen de la Madona de Madrid, esta abarcaría, por lo tanto, desde 1282 — año en el que el todavía infante Sancho $\mathrm{IV}^{60}$ tomó bajo su encomienda al convento de Santo Domingo el Real de Madrid, confirmando ese mismo año varios privilegios que sus predecesores habían concedido al cenobio madrileño- y $1295^{61}$. Datación que podría acotarse aún más a la luz de las semejanzas existentes entre la Madona de Madrid y la Virgen del monasterio cisterciense femenino de San Salvador de Cañas (La Rioja), imágenes que hasta ahora no habían sido puestas en relación.

\section{La Madona de Madrid y la Virgen de San Salvador de Cañas}

Si bien el rostro tanto de la Virgen como del Niño riojanos resultan algo más inexpresivos que en el caso de la Madona de Madrid ${ }^{62}$, las numerosas similitudes perceptibles entre ambas imágenes, como son la forma marcadamente triangular de los fiadores de Madre e Hijo, los plegados angulosos de la vestimenta de ambos y la casi exacta disposición y caída de estos en las dos imágenes, el fiador de la Virgen en forma de florón, con un elemento que pende de este en forma de lágrima, la estructura del sitial, además de la decoración de la peana con emblemas

59 Martínez de Aguirre / Menéndez Pidal, 1996: 171.

${ }^{60}$ A pesar de que la historiografía tradicional asegura que Sancho IV nunca se presentó como rey en vida de su padre, algunos documentos contradicen esta afirmación: Nieto, 2014: 39, nota 7.

${ }^{61}$ La donación de la Madona de Madrid por parte de Sancho IV a Santo Domingo el Real de Madrid habría coincidido con el priorazgo de dos de las principales superioras del cenobio madrileño en época medieval: sor Leocadia — documentada como priora en 1266, 1272, 1273, 1283, 1284, 1285 y 1287—y sor Urraca Díaz — documentada como priora en 1293, 1294 y 1297—, así como con los priorazgos de fray Miguel Pérez (1283), fray Pedro Peláez (1283), fray Domingo Bello o Ulloa (1284), fray Gil de Villamediana (1285), fray Pedro Peláez (1286) y fray Domingo Pérez (1293 y 1294). De conocer el año exacto en el que Sancho IV habría donado la Madona de Madrid al convento podríamos relacionar esta con alguno de los superiores arriba mencionados, sin embargo, carecemos de los datos documentales necesarios: Montero, 1994: 305 y 310-312; Romero, 2008: 117 y 121.

62 Esta inexpresividad podría haberse visto agudizada por repintes posteriores, como ocurrió en el caso de la Virgen de la Rosa de Nájera: Martiarena, 2001: 220. 
heráldicos individualizados con un claro carácter ornamental, hacen sospechar una posible relación entre ambas imágenes (fig. 10) ${ }^{63}$.

En efecto, como ya apuntó Clara Fernández-Ladreda, Nuestra Señora de Cañas pertenece, igualmente, al tipo vasco-navarro-riojano ${ }^{64}$. Los mencionados emblemas heráldicos que decoran la peana de la Virgen ${ }^{65}$, atribuidos, inicialmente, a los López de Haro y a los Castro, han llevado a la historiografía a relacionar esta imagen con la beata Urraca Díaz de Haro Ruiz de Castro ${ }^{66}$, hija de los fundadores del cenobio, Lope Díaz de Haro (ca. 11001170) y Aldonza Ruiz de Castro (1140-1205) ${ }^{67}$. Tras enviudar, doña Urraca se retiró al monasterio de Cañas, al que había estado vinculada desde que tenía apenas un año, siendo nombrada abadesa el 2 de septiembre de 1225 y permaneciendo en el cargo hasta $1262^{68}$.

Sin embargo, Ghislain Baury afirma, muy acertadamente, que sería más correcto datar la imagen de Nuestra Señora de Cañas, desde un punto de vista tanto formal como tipológico, a finales del siglo XIII ${ }^{69}$. En este sentido, resulta fundamental la aportación de Javier Martínez de Aguirre y Faustino Menéndez Pidal, quienes identificaron las armas que decoran la peana de esta imagen como las de los Haro y los Bearne $^{70}$. Emblemas que relacionarían la Virgen de Cañas con una de las abadesas del

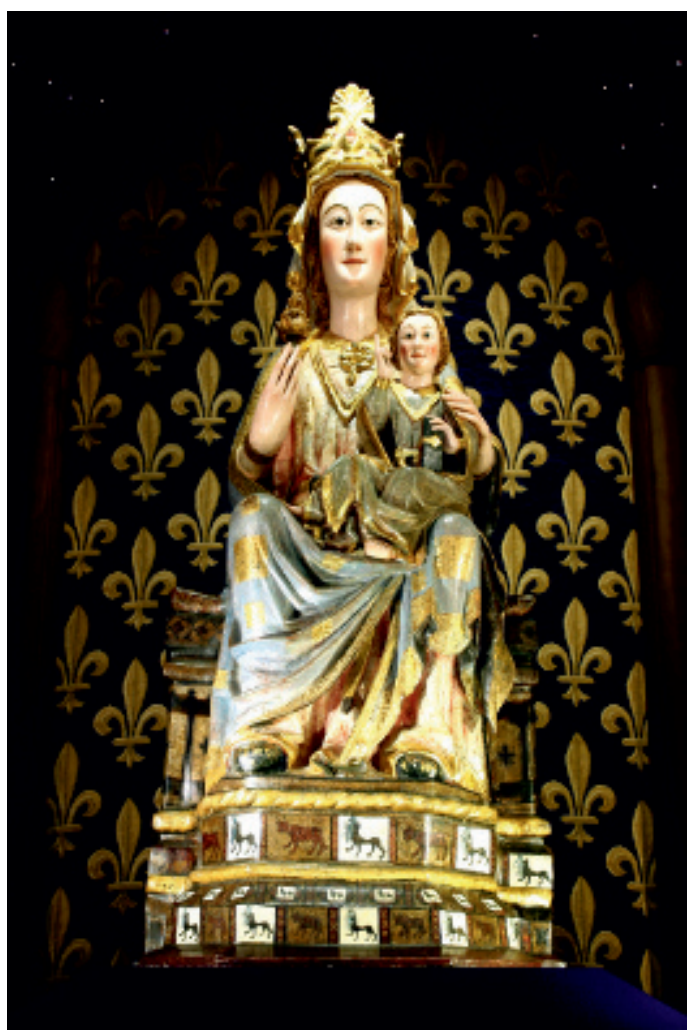

Fig. 10. Nuestra Señora de Cañas. Monasterio de San Salvador de Cañas (La Rioja). Fotografía de Juan Manuel Aguado Grijalba. monasterio riojano pero no con Urraca Díaz de Haro, sino con su sucesora en el cargo: Constanza de Bearne, viuda de Diego López III de Haro, documentada como abadesa entre 1262 y $1274^{71}$. Desconocemos su fecha de fallecimiento, aunque, según indica Enrique Marcos Pascual, en 1285, Constanza compró heredades y casas en Sotillo, y ocho almudes de sembradura y un collazo en Villaporquera ${ }^{72}$.

$\mathrm{O}$ bien durante su abadiazgo, o bien en fecha próxima a su muerte, y movida, quizás, por el deseo de dejar recuerdo de su persona, Constanza de Bearne habría donado la imagen de Nuestra

${ }^{63}$ La Virgen de Cañas ha sido también puesta en relación con la Virgen de Tuesta y la Virgen de la Rosa de Nájera, junto con las de Puebla de Arganzón, Larraza, Alegría (Álava) y Zarauz: Martiarena, 2001: 215. Véase también nota 60. Agradezco a Juan Manuel Aguado Grijalba el que me facilitase un reportaje fotográfico completo de la mencionada imagen mariana.

${ }^{64}$ Fernández-Ladreda 1989: 147, nota 21, y 163.

65 "En campo por determinar, un toro, con collar, y de otro, de plata, un lobo, uñado y dentado, cebado con un cordero, y bordura de gules cargada con doce aspas o cruces de San Andrés, de azur": Ruiz de Bucesta / Rodríguez de Maribona, 2015: 148.

${ }^{66}$ Moya, 1979: 20; Fresneda, 2012: 182.

${ }^{67}$ Abad, 1984: 49-58 y 225; Alonso, 2004: 37-5; Ruiz de Bucesta / Rodríguez de Maribona, 2015: 148-149; Marcos, 2016: 79-95.

68 Moya, 1979: 33; Abad, 1984: 97-100; Marcos, 2016: 95-97 y 140-146.

69 Ghislain, 2011: p. 170.

70 Martínez de Aguirre / Menéndez Pidal, 1996: 171.

71 Abad, 1984: 225; Alonso, 2004: 33-34 y Marcos, 2016: 146-147, apéndice documental II, 19.

72 Marcos, 2016: 147, apéndice documental III, docs. 68 y 72. 
Señora de Cañas al monasterio que fue su última morada, mandando decorar la peana con sus propias armas. La mencionada ligera rigidez e inexpresión de los rostros de la Virgen y el Niño riojanos hacen pensar en que la imagen de Cañas pudiese ser ligeramente anterior a la de Santo Domingo el Real de Madrid. Por su parte, las semejanzas formales apuntadas llevan a plantear la hipótesis de que Sancho IV pudiese haber tenido en mente la imagen riojana al encargar la realización de la Madona de Madrid o que, incluso, pudiese haber sido encargada al mismo artífice.

El 11 de junio de 1282, el todavía infante Sancho confirmó un privilegio dado por su padre al monasterio de San Salvador de Cañas para que los ganados de este "passen estreno y pazcan a donde los demás ganados que passan a estremo con que los que los guardaren paguen sus derechos a do lo debieran"73, dato que pondría de manifiesto la relación que el futuro Sancho IV habría establecido ya con el monasterio de San Salvador de Cañas en años previos a su reinado. Recordemos, además, que la abadesa Constanza de Bearne fue madre de Lope Díaz III de Haro, señor de Vizcaya, Orduña y Valmaseda, y privado de Sancho IV, y de Diego López V de Haro, quien casó con la infanta Violante de Castilla, hija de Alfonso X y, por lo tanto, hermana de Sancho IV ${ }^{74}$.

En el caso concreto de Lope Díaz III de Haro - vinculado a la causa del infante don Sancho desde el momento de su sublevación ${ }^{75}$ — es sabido la determinante influencia que este ejerció en los asuntos políticos del reino, como privado del monarca, entre 1287 y 1288 — situación definida por José Manuel Nieto Soria como de "libertad vigilada por el propio monarca"76 _, pudiendo haberse tallado la Madona de Madrid durante este período de tiempo.

\section{Conclusiones}

En conclusión, los castillos y leones que decoran la peana de La Madona de Madrid han llevado a quienes se han aproximado a su estudio a relacionar esta imagen con diversos reyes y personajes próximos a la monarquía castellana, como Fernando III, Pedro I, Enrique II y sor Constanza de Castilla, dándole una cronología que abarca desde 1219 hasta 1478. Resultaba, por lo tanto, necesario tratar de precisar la datación de la misma, así como la identidad de su comitente, habiendo sido de especial ayuda en este proceso la aportación de Clara Fernández-Ladreda, quien, ya en 1989, relacionó la Virgen con Niño de Santo Domingo el Real de Madrid con el tipo vasco-navarro-riojano.

Al examinar los datos documentales conservados relativos al patronazgo regio del convento madrileño durante el último tercio del siglo XIII, período cronológico que concuerda con el momento de difusión del mencionado tipo mariano, y coincidente con los reinados de Alfonso X, Sancho IV y Fernando IV, se ha podido comprobar la estrecha relación que el segundo de ellos mantuvo a lo largo de su reinado, e, incluso, en años previos a este, con el convento de Santo Domingo el Real de Madrid, puesto que en 1282, siendo aún infante, acogió al cenobio bajo su protección.

Los citados castillos y leones que decoran la peana de la Madona de Madrid, la devoción mariana del monarca, así como la existencia de otras imágenes marianas pertenecientes, al igual

73 Marcos, 2016: apéndice documental III, doc. 71.

74 Gaibrois, 1922: tomo 1, 133; Ballesteros, 1984: 520; Lucas, 1986: 67-68; Nieto, 2014: 76.

75 Nieto, 2014: 76.

76 El 1 de enero de 1287, en Valladolid, Lope Díaz III de Haro fue nombrado por el rey mayordomo mayor y alférez mayor de Castilla, a la vez que obtenía el título de conde, el cual, a pesar de haber caído en desuso, ponía de relieve la situación preeminente del privado en el conjunto de la nobleza castellana. Ese día, el rey se comprometió a "facerle merced e bien en guisa que fuese el mayor ome e más honrado del reino". El 8 de junio de 1288, en Alfaro, se ponía fin a la privanza de Lope Díaz III de Haro con la muerte del propio conde a manos de los hombres del rey. Por su parte, Diego López V de Haro (†1310), ocupó los cargos de alférez, adelantado mayor de Castilla y adelantado de frontera en la corte de Sancho IV, volviendo a estar al servicio del rey durante el reinado de Fernando IV: Gaibrois, 1922: tomo I, 132 y 190-193; Lucas, 1986: 45-47, 71-76 y 135-139; Nieto, 2014: 77 y 84-85; Nieto, 2014: 75. 
que la Virgen con Niño madrileña, al tipo vasco-navarro-riojano, que habrían sido donadas o bien por el propio Sancho IV — como, por ejemplo, Nuestra Señora de la Vid-, o bien por miembros de su séquito - como sería el caso de la Virgen de Fitero-, señalarían a Sancho IV como posible donante de la imagen, la cual habría sido realizada entre 1282 y 1295, pudiéndose, quizás, datar la ejecución de la pieza entre 1287 y 1288 — período que coincide con la privanza de Lope Díaz III de Haro-, debido a las semejanzas existentes entre la Madona de Madrid y la Virgen de Cañas, donada, esta última, por Constanza de Bearne, madre del privado del rey, al monasterio riojano del que fue abadesa.

\section{BIBLIOGRAFÍA}

Abad León, Felipe (1984): Real Monasterio de Cañas. Nueve siglos de fidelidad. Logroño: Editorial Ochoa.

Aguado Grijalba, Juan Manuel (coord.) (2001): Guía. Abadia Cisterciense de Cañas. Logroño: Fundación Caja Rioja.

Alonso Getino, Luis G. (1919): “Centenario y Cartulario de nuestra Comunidad”. En: Ciencia Tomista, 19, Salamanca, pp. 5-20, $127-143$ y $253-272$.

Ara Gil, Clementina-Julia (1977): Escultura gótica en Valladolid y su provincia. Valladolid: Institución Cultural Simancas, Diputación Provincial de Valladolid.

Amador de los Ríos, José (1978): Historia de la Villa y Corte de Madrid, tomo I. Madrid: Ábaco ediciones.

Ballesteros Beretta, Antonio (1984): Alfonso X el Sabio. Barcelona: El Albir.

Bango Torviso, Isidro (2001): "De las insignias reales en la España medieval". En: Imágenes y promotores en el arte medieval. Miscelánea en homenaje a Joaquín Yarza Luaces. Barcelona: Universitat Autònoma de Barcelona, pp. 59-66.

Bernis, Carmen (1970): “La moda y las imágenes góticas de la Virgen. Claves para su fechación”. En: Archivo Español de Arte, 43, 170, Madrid, pp. 193-218.

Carrasco Lazareno, María Teresa (1994): La documentación de Santo Domingo el Real de Madrid (1284-1416), tesis doctoral inédita, vol. II. Colección diplomática. Madrid: Universidad Autónoma de Madrid.

Domínguez Sánchez, Santiago (2003): "Falsificaciones medievales. Una 'bula' de Nicolás IV falsificada por el rey Sancho IV de Castilla”. En: Estudios Humanísticos. Historia, 2, León, pp. 13-25.

Estella Marcos, Margarita (1978): "El convento de Santo Domingo el Real de Madrid". En: Villa de Madrid. Revista del Excmo. Ayuntamiento, 59, Madrid, pp. 59-67.

Fernández-Ladreda, Clara (1989): Imaginería medieval mariana. Pamplona: Gobierno de Navarra.

Fernández-Ladreda, Clara (2001): "Las imágenes de la Virgen en la escultura". En Bango Torviso, Isidro G. (dir.): Maravillas de la España medieval. Tesoro sagrado y monarquía. Madrid: Junta de Castilla y León y Caja España, tomo I.

Flórez, Enrique (1767): España sagrada: Theatro geographico-historico de la iglesia de España. Continuación de las memorias de la Santa Iglesia de Tuy y colección de los chronicones pequeños publicados è ineditos de la Historia de España, tomo XXIII. Madrid: Antonio Marín.

Fresneda González, María de las Nieves (2012): Atuendo, aderezo, pócimas y ungüentos femeninos en la Corona de Castilla (siglos XIII y XIV), tesis doctoral inédita. Madrid, Universidad Complutense de Madrid, tomo I.

Gaibrois de Ballesteros, Mercedes (1922-1928): Historia del reinado de Sancho IV. Madrid: Tipografía de la Revista de Archivos, Bibliotecas y Museos, 3 vols.

Ghislain, Baury (2011): "Sainteté, mémoire et lignage des abbesses cisterciennes de Castille au XIIIe s. La Comtesse Urraca de Cañas (av. 1207-1262)". En: Anuario de Estudios Medievales, 41/1, Barcelona, pp. 151-182.

González Zymla, Herbert (2005): "El patrimonio medieval del exclaustrado convento de Santo Domingo el Real de Madrid: nuevas fuentes y documentos para el estudio de su panteón real”. En: Madrid. Revista de arte, geografia e historia, 7, Madrid, pp. 43-93.

Gutiérrez Baños, Fernando (1997): Las empresas artísticas de Sancho IV el Bravo. Burgos: Junta de Castilla y León, Consejería de Educación y Cultura.

Gutiérrez Baños, Fernando (2001): "Sancho IV en la Ribera del Duero: el testimonio de su labor de promoción de las artes". En: Biblioteca. Estudio e Investigación, 16, Aranda de Duero, pp. 255-285.

Huarte, Amalio (1925): Nuestra Señora de Madrid. Madrid: Ayuntamiento de Madrid.

López Dapena, Asunción (1984): Cuentas y gastos (1292-1294) del rey D. Sancho IV el Bravo (1284-1295). Córdoba: Publicaciones del Monte de Piedad y Caja de Ahorros de Córdoba.

López de Guereñu, Gerardo (1982): Andra Maria en Álava. Iconografía mariana de la diócesis de Vitoria. Vitoria: Diputación Foral de Álava.

Lucas de la Fuente, Julián (1986): D. Diego López de Haro V: Magnate de Castilla, Señor de Vizcaya y fundador de Bilbao. Bilbao: Caja de Ahorros Vizcaína.

Marcos Pascual, Enrique (2016): Historia y jurisdicción de las abadesas del monasterio de Cañas en la Edad Media. Logroño: Instituto de Estudios Riojanos.

Martiarena Lasa, Xabier (2001): "La aparición de una bella sonrisa, Virgen de la Rosa de Nájera". En: Berceo, 140, Logroño, pp. 213-240.

Archivo Español de Arte, vol. XCI, n. ${ }^{\circ} 364$, pp. 333-348, octubre-diciembre 2018 ISSN: 0004-0428, eISSN: 1988-8511, https://doi.org/10.3989/aearte.2018.20 
Martínez de Aguirre, Javier / Menéndez Pidal, Faustino (1996): Emblemas heráldicos en el arte medieval navarro. Pamplona: Gobierno de Navarra.

Martínez Martínez, María José (1991): "Imaginería medieval mariana en la Ribera”. En: Biblioteca. Estudio e investigación, 6, Aranda de Duero, pp. 143-158.

Menéndez Pidal, Faustino (1991): "Desarrollo y crisis del sistema heráldico (siglos XIII-XV)". En: Anales de la Real Academia Matritense de Heráldica y Genealogía, 1, Madrid, pp. 87-100.

Menéndez Pidal, Faustino (2004): El escudo de España. Madrid: Real Academia Matritense de Heráldica y Genealogía.

Montero Vallejo, Manuel (1994): "Las prioras del monasterio de Santo Domingo el Real de Madrid durante la Edad Media”. En: Anales del Instituto de Estudios Madrileños, XXXIV, Madrid, pp. 293-318.

Moreta Velayos, Salustiano (1996): "Notas sobre el franciscanismo y el dominicanismo de Sancho IV y María de Molina”. En: VI Semana de Estudios Medievales de Nájera. Nájera: Instituto de Estudios Riojanos, pp. 171-184.

Moya Valgañón, José G. (1979): El monasterio de Cañas y su museo. Logroño: Servicio de Publicaciones de la Unidad de Cultura de la Excma. Diputación de Logroño.

Nieto Soria. José Manuel (2014): Sancho IV de Castilla (1284-1295). Gijón: Ediciones Trea.

Nieva Ocampo, Guillermo (2011): "Los dominicos en Castilla. La génesis de una corporación privilegiada en la baja edad media". En: Nieva Ocampo, Guillermo / Benito Moya, Silvano G. A. / Mariana Navarro, Andrea (coords.): Servir a Dios y servir al Rey: el mundo de los privilegiados en el ámbito hispánico (ss. XII-XVIII). Salta: Mundo Gráfico Salta Editorial, pp. 13-48.

Nogales Rincón, David (2009): La representación religiosa de la monarquía castellano-leonesa: la capilla real (12521504), tesis doctoral inédita, vol. I. Madrid: Universidad Complutense de Madrid.

Pardo de Guevara, Eduardo (1987): Manual de heráldica española. Madrid: Aldaba Ediciones.

Pérez de Tudela y Velasco, María Isabel (1985): "Madrid en la documentación de Santo Domingo el Real". En: En la España Medieval, 7, Madrid, pp. 991-1010.

Pérez Vidal, Mercedes (2011): “QQuinze imágenes de nuestra señora’. Arte y devoción mariana en el monasterio de Santo Domingo el Real de Madrid”. En: Francisco Javier Campos y Fernández de Sevilla (coord.): La clausura femenina en el Mundo Hispánico: una fidelidad secular. Simposium (XIX Edición) San Lorenzo de El Escorial, del 2 al 5 de septiembre de 2011. El Escorial: Real Centro Universitario Escorial-María Cristina, vol. II, pp. 921-944.

Rada y Delgado, Juan de Dios de la (1869): "Santo Domingo el Real de Madrid (I)". En: Boletín-Revista de la Universidad de Madrid, I, 4, Madrid, pp. 219-223.

Rada y Delgado. Juan de Dios de la (1869): "Santo Domingo el Real de Madrid (II)". En: Boletín-Revista de la Universidad de Madrid, I, 5, Madrid, pp. 276-286.

Real González, Julio (2011): "El monasterio de Santo Domingo el Real y la Madona de Madrid". En: La Gatera de la Villa, 7, Madrid, pp. 55-63.

Roger de Cardinal, Susana (2010): "Los monasterios y la monarquía en época de crisis: Sancho IV”. En: Estudios de Historia de España, XII, 2, Buenos Aires, pp. 467-488.

Romero Fernández-Pacheco, Juan Ramón (2008): Santo Domingo el Real de Madrid. Ordenación económica de un señorio conventual durante la baja edad media (1219-1530). Salamanca: Editorial San Esteban.

Rosell y Torres, Isidoro (1875): "La Madona de Madrid, antigua imagen del demolido monasterio de Santo Domingo el Real". En: Museo Español de Antigüedades, tomo V, Madrid, Madrid, pp. 163-173.

Ruiz de Bucesta y Álvarez, Manuel Luis / Rodríguez de Maribona y Dávila, Manuel María (2015): "Heráldica en el real monasterio cisterciense de Santa María de San Salvador de Cañas". En: Boletín (Asociación Riojana de Genealogía y Heráldica), 7, Logroño, 139-162.

Sáez Lerena, José Luis (2000): Real Patronato de Santa María la Real. Cuarenta años. Nájera, Real Patronato de Santa María la Real de Nájera.

Tabar Anitua, Fernando (2007): "Virgen Blanca o Andra Mari de Tuesta". En: Exposición Canciller Ayala, del 18 de abril al 26 de julio de 2007, Catedral Nueva María Inmaculada, Vitoria-Gasteiz. Vitoria: Diputación Foral de Álava, pp. 236-239.

Vicente, J. F. (comisario) (1986): Exposición conmemorativa del primer centenario de la diócesis de Madrid-Alcalá. Madrid: Caja de Ahorros y Monte de Piedad de Madrid.

Fecha de recepción: 25-VII-2017

Fecha de aceptación: 06-XI-2017 